IN VITRO AND EX VIVO EVALUATION OF N-METHYL BENZILATES AS POTENTIAL PET AGENTS FOR MUSCARINIC RECEPTORS

C.A. Otto, G.K. Mulholland, S.E. Perry, R. Combs, P.S. Sherman and S.K. Fisher Department of Natural Sciences, Iniversity of Michigan-Dearborn, Dearborn, MI 48128 and Division of Nuclear Medicine, University of Michigan Medical Center, Ann Arbor. MI 48109 USA

The apparent association between muscarinic receptors (InAChR) and cognitive functions together with the strong association of damage to muscarinic areas of the brain and onset of certain dementias such as Alzheimers has prompted an effort to develop new mAChR imaging agents. Potent antagonists of mAChR, particularly piperidyl and tropanyl esters of benzilic acid $(1, ?)$ were used to generate a list of ligands amenable to straight-forward labeling with high specific activity carbon-11. These ligands were selected for further evaluation: 4-N-methylpiperidyl benzilate (NMPB), (+)-tropanyl benzilate (TRB), scopolamine and quinuclidinyl benzilate (QNB). The "nor" derivatives of NMPB, TRB and Scopolamine (PB, nor-TRB, and nor-scopolamine) were also included to assess possible metabolites.

In order to avoid radiosynthesis of each prospective ligand, a potentially time consuming and expensive process, a screening procedure which would provide information on both binding affinity and in vivo distribution of the ligands was sought. The procedure employed consisted of two parts: 1) a traditional in vitro competitive binding assay using $3 \mathrm{H}-\mathrm{QNB}$ and mouse brain homogenates and 2) an ex vivo assay in which the availability of receptors was measured after in vivo injection of the ligand, sacrifice and in vitro binding of $3 \mathrm{H}-\mathrm{QNB}$.

Table 1 contains the IC50 values obtained for each compound. These values indicated that QNB, scopolamine, NMPB, TRB and nor-TRB had potential as imaging agents. Demethylation reduces the affinity for scopolamine, TRB and NMPB but the greatest effect was observed for NMPB.

To validate the use of the ex vivo assay several studies were completed. First, it was determined that different ligands did affect the degree of receptor occupancy when equimolar solutions were administered. Table 2 summarizes the results for four of the ligands: TRB and nor-TRB were about twice as effective at blocking mAChR than the other ligands. Second, the effect of variation of moles 1 igand injected was determined. TRB occupies more receptors than either scopolamine or NMPB from $1 \times 10^{-6}$ to $1 \times 10^{-5} \mathrm{M}$ (moles ligand $/ \mathrm{kg}$ body weight). At $1 \times 10^{-7} \mathrm{M}$, no differences between control (saline) and experimental tissues could be detected for any of the ligands. Third, the effect of time on receptor occupancy was examined. Receptor occupancy for QNB and TRB was determined in both brain and heart. TRB, at 2 min post injection, occupied about the same number of receptors as QNB, however the availability of receptors for $3 \mathrm{H}-\mathrm{QNB}$ binding in the brain increased almost twice as fast for TRB compared to QNB. In the heart, the availability increased almost four times faster for TRB compared to QNB.

The combination of in vitro competitive binding assays and ex vivo binding assays suggests that TRB has significant potential for mAChR imaging: 1) the binding affinity of TRB is comparable to that of QNB, 2) TRB is more amenable to labeling with carbon-11 than QNB, 3) the increased rate of washout from the brain may avoid the problems of long retention associated with QNB. Based on these studies, carbon-11 TRB has been synthesized and evaluated. Details of the radiosynthesis and evaluation of TRB will be reported elsewhere (3). 
Table 1. IC 50 values for potential mAChR ligands from competitive binding assays using ${ }^{H} \mathrm{H}-\mathrm{QNB}$ and mouse brain homogenates.

$\begin{array}{lc}\text { Ligand } & \text { IC } 50, \mathrm{nM} \\ \text { QNB } & 0.8 \pm .2 \\ \text { Scopolamine } & 1.3 \pm .3 \\ \text { Nor-scopolamine } & 6.9 \pm .9 \\ \text { NMPB } & 1.8 \pm .1 \\ \text { PB } & 17.3 \pm 2.7 \\ \text { TRB } & 0.7 \pm .3 \\ \text { Nor-TRB } & 1.3 \pm .4\end{array}$

Table 2. Percentage of ${ }^{3} \mathrm{H}-\mathrm{QNB}$ binding relative to controls after in vivo drug administration. Ligand concentration was $1 \times 10^{-5}$ moles $7 \mathrm{~kg}$ mouse; sacrifice at $t=45 \mathrm{~min}$.

Ligand

Saline

Scopolamine

TRB

Nor-TRB

NMPB

\section{Percent of control}

100

65

35

37

74

1. Atkinson, E.R., McRitchie, D.D., Shoer, L.F., Harris, L.S., Archer, S., Aceto, M.D., Pearl, J., and Luduena, F.P., J. Med. Chem. 20, 1612 (1977).

2. Kloog, Y. and Sokolovsky, M., Brain Res. 134, 167 (1977).

3. Mulholland, G.K., Dtto, C.A., Jewett, D.M., Kilbourn, M.R., Sherman, P.S., Koeppe, R.A., Kuhl, D.E., submitted to Proceedings Seventh International Symposium on Radiopharmaceutical Chemistry, Groningen. The Netherlands, 1988. 